\title{
HOW PLURALISM BECOMES HIERARCHICAL? DEBATING PLURALISM IN CONTEMPORARY POLAND'
}

\author{
INTRODUCTION
}

T he multireligious and multiethnic commune ${ }^{2}$ of Uście Gorlickie, situated in the Matopolska region, has recently been described as "a pearl of multiculturalism" and "perhaps the most ecumenical region in all of Poland." 3 This is due to the fact that this agricultural-touristic commune is inhabited by seven religious communities and two ethnic groups, which "coexist in peace." As such, not only does it differ from the rest of the region but it constitutes a rather idiosyncratic setting within the mostly homogenous Polish realm. The definition of the commune as "multicultural" undoubtedly pleases many local actors. The owners of farm tourisms perceive it as a good promotional strategy, the local government strives to use it for fund-raising, while journalists find in it a catchy subject to write about. It seems that only the "average" inhabitants, and especially minority representatives whose well-being is, at least in theory, the main concern of the new multicultural policies, treat the idea of "multiculturalism" with reservation and irony. Asked about the interreligious relations in the area, they wink and answer with a wry smile: "Well, we've got multiculturalism today!"

An increasingly important locality in the "multicultural commune" is the health resort of Wysowa Zdrój,

Agnieszka PASIEKA, Ph. D.

The Institute of Slavic Studies,

Polish Academy of Sciences. aga.pasieka@gmail.pl

1 The article is based on the research co-funded by the Max Planck Institute for Social Anthropology and the Volkswagen Foundation. The work on the article was possible thanks to the grant of the National Centre of Science (DEC-2012/04/S/HS3/00370).

2 "Commune" refers to the administrative unit (gmina).

3 See, e.g., Podraza 2009a, 2009b. See also the representation of the Malopolska region http://www.malopolskie.pl/wydawnictwa/index.aspx?id=40 
which attracts tourists due to the presence of several sanatoria, an industry of mineral waters as well as a well-developed tourism infrastructure. In recent years, the local government has made sizeable investments in the health resort. It renovated a big park and surrounding area, rebuilt a wooden pump room which burnt down in the 1960s and constructed a modern swimming pool. All these spots attract numerous visitors, who are invited to stop for a glass of water and discover the rich history of the commune. Still, a closer investigation of the cultural initiatives and "multicultural encounters" in the park reveals that some religious and ethnic communities are more welcomed than others and that while the presence of some seems to be a "natural" element of the local landscape, the other ones are perceived as an "exotic" addition.

The aim of my paper is to discuss the mechanisms that put into motion precisely this paradox: the fact that while advancing the claims of equality and diversity, the idea of pluralism — in its manifold incarnations ${ }^{4}$ —reproduces inequalities and naturalizes hierarchies between communities, traditions, and dogmas. In order to illuminate this problem, I first present a theoretical discussion and then refer it to the ethnographic evidence. Additionally, I combine an exploration of a concrete ethnographic setting with an investigation of the broader implications of locally observed phenomena.

In so doing, I hope to evince the importance of anthropological perspective in the study of pluralism, or rather: the importance of a thorough dialogue between theory and ethnography. For I contend that the deficiency in such a dialogue brings about two opposite, yet equally problematic, outcomes: the first is the perception of certain phenomena as unthinkable or meaningless in certain contexts, and the second-the attempt to transplant certain ideas from one context to another without paying attention to the local circumstances. I believe that the debates on pluralism, diversity or multiculturalism in Poland well illustrate both these issues; the idea of "pluralism in Poland" is either perceived as a contradiction in terms or it is applied "by default." Hence, the question of how to understand pluralism and whether it is "applicable" in different contexts seems a good point of departure.

\section{ON PLURALISM}

\section{Pluralism: from descriptive to normative approaches}

In discussing the importance of the anthropological perspective, it is worth highlighting that the first important works concerning the questions of "pluralism" and "plurality" came from anthropologists. In classical anthropological writings, the discussion of pluralism initially served the purpose of developing analytical tools for the study of "plural societies." For instance, John Furnivall proposed (1948:305) to distinguish "societies with plural features" from "plural societies", the former being characterized by a mixed population and a common tradition (such as the US or Canada), while the latter refer to colonial societies, which were the objects of anthropological inquiry at the time. Similarly, Michael Smith insisted (1960) on distinguishing between pluralism and other forms of social heterogeneity. He stressed that "pluralism" denotes the coexistence of incompatible institutional systems, but only one of these-the political—holds diverse groups together. Thus, in a "plural society," different groups ("cultural sections") are incorporated into one

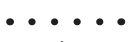

4 I explain below the relation between multiculturalism and pluralism. 
polity which is dominated by one group-a numerical minority. A similar understanding was proposed by Pierre van den Berghe (1973:961) who declared "pluralism" to be characteristic of societies in which the relations between different social/cultural groups are interdependent in economic terms, while being relatively autonomous in other spheres, e.g. the familial or religious sphere. Although this kind of scholarship was criticized for over-emphasizing "culture" (Despres 1968:11) and underestimating "social action" (Braithwaite 1960:823)—later it was also criticized for its colonial legacies (Vincent 1990) - what is worth saving from it is its (particularly Smith's) objection to reducing cultural and social pluralism to social stratification (as difference and stratification may vary independently) (Smith 1960:770, 774-5) and his insistence on analyzing pluralism as a dimension of society (1960:772) or as "a matter of degree" (den Berghe 1973:967). Moreover, it is worth remembering the importance of this scholarship in overcoming the drawbacks of functionalist analyses (cf. Kuper and Smith 1971) and opening new questions about the cohesion of the (heterogeneous) system.

More recent scholarship on pluralism and plural societies demonstrates an observable shift from analytical to ethical/moral categorizations. For many scholars, speaking about pluralism is equivalent to taking a normative standpoint, whereas analyses of plurality simply describe observed reality. As Diana Eck puts it (2006): "Pluralism» and "diversity" are sometimes used as if they were synonyms, but diversity is just plurality, plain and simple-splendid, colorful, perhaps threatening. Pluralism is the engagement that creates a common society from all that plurality." In other words, pluralism is one of other possible responses to diversity, a particular way of managing diversity, a project, and an achievement, rather than a given state. A similar opinion is presented by Rod Ling and Gary Bouma, who, when referring specifically to religious diversity, stress (2009:508) that certain societies are religiously plural but do not have pluralism-they lack the culture "favoring diversity." By the same token, Pamela Klassen and Courney Bender approach (2010:2) pluralism as "a commitment to recognize and understand others across perceived or claimed lines of religious difference." Thus, rather than denoting the social organization of difference, pluralism indicates a standpoint towards difference. Observably, as was the case in the discussion of "plural societies," this understanding of pluralism needs to be seen as the outcome of a specific historical-political context. Discussions of pluralism, which are taking place under different headings (such as multiculturalism, "politics of recognition" or "management of diversity"), are no doubt dominated by the contemporary phenomena of growing societal mobility, migrations, and globalized social movements. This enhances, on the one hand, awareness that pluralism is a category in which descriptive, analytical, and "policy-making" dimensions overlap, and, on the other hand, the necessity of contextualizing and historicizing pluralism in every case.

Two problems are especially important here. The first regards the functioning of pluralism as a political project. This issue has been cogently analyzed by Johannes Fabian, who argues that "[i]n the current jargon of politicians, journalists and, it seems, theologians [...] pluralism has almost always (but, of course, not always consciously) the function to cover up for, distract attention from, elevate to a level of abstract inevitability, relations of unequal multiplicity" (1985:139). Therefore, engaging crucially with the politics of pluralism, Fabian argues about the necessity to study "pluralism from below" by which he means an inquiry into how local people engage with and respond to pluralism. Following his advice, in my article I am going to focus on "pluralism from below" and, at the same time, highlight the dialectical relation between "pluralism from below" and "pluralism from above." 
The second point is the prominence of the discourse of "multiculturalism" in recent analyses of ethnically and religiously diverse societies. To be clear, it is not my aim to discuss the differences and similarities between "pluralism" and "multiculturalism." A detailed discussion of this issue would need to involve a thorough analysis of different philosophical and political traditions as well as socio-political contexts. In this article, I approach "multiculturalism" as a variant of pluralism and I contend that while both pluralism and multiculturalism focus on plurality, the latter one makes it clear that this plurality should be analyzed and addressed through the lenses of culture(s). Thus, what interests me most, are the implications of the multiculturalist discourse for the understanding of religiously and ethnically diverse societies. The discussion of this problem follows in the next section.

\section{Pluralism, multiculturalism, and inequalities}

As a matter of fact, the discussion of "pluralism" and "plurality" resemblances the discussion of "diversity" and "difference," which constitutes the core of multicultural debate. According to Thomas H. Eriksen (2006:14), "diversity" and "difference" reflect two fundamentally different ways of dealing with cultural variation: the first denotes "largely aesthetic, politically and morally neutral expressions of cultural difference," while the second refers to "morally objectionable or at least questionable notions and practices in a minority group or category." He shows that "diversity" is often conceived of in terms of exotic food and colorful rituals, and thus perceived as creative and enriching, while "difference" is seen as threatening. This argument supplements, in my view, the above quoted statement on pluralism as "covering up" inequalities, which in this instance means a kind of "pick-and-choose" diversity, selecting what one likes or what is profitable and rejecting what is disturbing. Christianne Harzig and Danielle Juteau (2003:4-5) present a similar argument, yet discuss not a dichotomy but a triad: diversity, difference, and differentiation. While they conceive of the relationship between difference and diversity in the way Eriksen does, they also stress the need to study the process of differentiation, which involves hierarchization. They consider it crucial to focus on the construction of difference and on power relations, in other words, to locate the making of difference within relationships of inequality. This leads them to conclude that pluralism has to be seen "in terms of diversity and difference, never eluding social relations of domination yet not reducing group dynamics solely to this dimension." (Harzig and Juteau 2003:5)

Reproduction of inequalities, simplification and reification of cultural difference are the key issues in the critique of the doctrine of multiculturalism, which come from different academic milieus. For instance, philosophers argue about the necessity of finding a middle ground between communitarian and liberal strands of multiculturalism, reconciling the idea of cultural difference with the idea of universal human rights. In turn, sociologists and political scientists are preoccupied mainly with the practical implications and consequences of multicultural policies, indicating drawbacks and dysfunctions of the "multicultural agenda." However, given the subject of my article, the anthropologists' contribution to the debate appears to be the most important. What is crucial in it is the fact that not only do anthropologists engage with the idea of "multiculturalism," but they take under scrutiny the very idea of "culture." They challenge an essentialist approach to culture and the idea of culture as permanently inscribed to an individual or a community. At the same time, they oppose a simplistic critique of multiculturalism (e.g. Vertovec and Wessendorf 2009) and 
indicate the potential of anthropology in shaping the discourse on diversity and empowerment of minorities (Eller 1997; Turner 1993). In other words, rather than rejecting multiculturalism as such, they indicate that it is the lack of reflection on the very idea of culturein the main the question of its changeable nature and interaction with other components of one's identity-to make multiculturalist discourses problematic and multicultural policies unsuccessful. As Wojciech Burszta observes (1997: 27; 2005: 153), instead of becoming a means of social mobility, cultural identities become a prison, preventing intercultural interactions and dialogue and highlighting the separation of different "cultures." Speaking directly to the Polish context, it is worth adding that instead of promoting diversity and empowering minorities, multiculturalism often turns into the promotion of the majority, which uses the discourse of multiculturalism to separate "cultural others" and to establish what is to be understood as "national culture" (see Pasieka forth.).

Summing up, the studies on "plural" and "multicultural" societies shed light on the complexity of hierarchical relationships. Most scholars state more or less clearly that pluralism does not entail equality. A number of anthropologists point this out: for example, the above mentioned Fabian (1995) describes pluralism as a means of masking inequalities while Eriksen (2006) explores the processes which make the hierarchical aspects of majority-minority relations invisible. In her discussion of multiculturalism, Joan Scott (1992) perceives the difference and the salience of difference as a product of discrimination while Katherine Verdery (2000) recognizes that the praise of heterogeneity harbors the danger of essentialization and represents a variation of homogenizing projects. Therefore, any study of pluralism needs to take into consideration the problem of domination and approach it as a set of social relations which are constitutive of dominant and subordinate groups, of majorities and minorities (Juteau 2003:252-3). Yet, while most contemporary scholars recognize the interconnection between pluralism and power relations, the dynamics of this relation is less obvious. Thus, in the following, I want to examine the question how vertical forms of differentiation are produced and made to come across as inherent-how pluralism becomes hierarchical.

Hierarchical pluralism

In order to illuminate this process, I would like to recall the seminal works of Pierre Bourdieu (1977, 1992). Bourdieu argued that socio-cultural reproduction should be seen as the result of "symbolic violence" which aims to establish order and meaning in the social world and influence people's worldviews and practices. Symbolic violence is a "gentle, disguised form of violence" (1992:133) and it is powerful because it is located in the least "suspicious" spheres, such as religion. In one of his key explications of religious power, Bourdieu (1971a:328-9) describes how religious and political authorities attempt to dominate people's perceptions, by legitimizing and "naturalizing" the existing social order. This process is evident, for example, in the distinction between "true religion" and "heresy" (Furseth 2009:102), which establishes what is "correct" and "normal" and what is "wrong" and "abnormal." Domination of perceptions is crucial for Bourdieu, as it leads to a situation in which dominated groups diminish themselves and start to see their own positions through the eyes of the dominant group/culture and in accordance with the established order. Underlying this mechanism is the imposition of the "binding rules" of the social world as natural and normal rules. They become doxa-taken-for-granted views 
of how things work, they make the social order self-evident so that it "goes without saying because it comes without saying" (Bourdieu 1977:167). As such, the rules appear to be obvious and do not need to be justified. Also, this kind of dominance, which is based on various kinds of doxa, may pass "unnoticed" and it is precisely for this reason that it is so powerful in creating inequality.

First, doxa provides people with what Bourdieu calls "the sense of reality" (1977:164) and with an understanding of what is appropriate for their positions. Second, as mechanisms of power are hidden, a situation arises in which factual inequality is masked by declared equality. Nevertheless, Bourdieu indicates the possibility of alternative and antagonistic beliefs - heterodox views (1977:164) or opinions (1977:167-8) - which open a sphere where established norms and truths can be contested and confronted and where discourses compete with one another. The struggle for power and symbolic violence occur, therefore, on the frontline between doxa and opinions and this frontline is constantly negotiated and altered. While the less powerful individuals or groups attempt to challenge doxa and expose the arbitrariness of the "taken-for-granted," the dominant individuals or groups strive to maintain the integrity of the "taken-for-granted" (1977: 169). Hence, the hierarchy-of people, norms, and beliefs-is established through the naturalization of the arbitrary and the imposition of the existing social order as "normal."

In the Polish context, doxa is the conviction that (a good) Pole is Catholic or that Catholicism is the "normal" religion in Poland. This view is imposed by different means of symbolic violence, many of which he discusses in detail (see Bourdieu and Passeron 2000). I argue that the idea of "Pole-Catholic" is promoted and reinforced by different state's and Church's policies and deeply internalized and referred to by minority groups. What I mean here are, for instance, the contemporary historical politics, education, and broadly understood cultural production which make clear what is to be considered Polish identity, Polish heritage or Polish tradition. Crucially, such a view is often promoted by "multiculturalist" discourse which, rather than promoting a pluralized view of Poland, reinforces the image of the Polish-Catholic culture vis-à-vis other "cultures" (Pasieka forth.).

Therefore, I propose to understand "hierarchical pluralism" as the changeable configuration of social relations, which allows and acknowledges diversity while making it clear which (ethnic/religious) group is dominant and norm-defining. In other words, in introducing this notion I highlight a situation in which declared equality serves to mask factual inequality. Referring to a seminal conceptualization of hierarchy by Louis Dumont (1980), it should be observed that hierarchical order thus understood does not eliminate but accepts and encompasses differences; however, the very act of accepting or encompassing displays who has the power to accept and who seeks to be accepted. All these observations guide the following study of pluralism in Uście Gorlickie, which starts with a short historical overview.

\section{PLURALISM IN UŚCIE GORLICKIE}

\section{A history of local pluralism}

Until the Second World War, the commune of Uście Gorlickie lat the time known as Uście Ruskie) as well as the entire region of Lower Beskid and Bieszczady, was inhabited nearly exclusively by the Rusyn (Ruthenian) population. The main boundary marker between Rusyn and Polish peasants was religion as a vast majority of Rusyns practiced 
Eastern Christianity. In the interwar period, the only "others" living in Rusyn villages were a couple of Jewish and Polish families. According to the oldest inhabitants, there was a distance between the Jews and the Rusyns due to the separateness of religious and economic spheres, while Poles were usually integrated in the local community and participated in the services in a cerkiew. Nevertheless, the system of the ethnic and religious landscape was far from stable. Due to the growing importance of nationalist movements, the Rusyn population was subjected to different influences and policies. As a result, some people came to identify themselves as Ukrainians, while others highlighted their separateness from the Ukrainian nation, stressed their "Rusyn" identity and started to be referred to as Lemkos. It is noteworthy that a vast group of local people was indifferent and did not identify with any camp (Wójtowicz-Huber 2008). The following piece from a school chronicle from the interwar period well illustrates this point:

In the Ukrainian bloc, there are mainly students, members of the intelligentsia, and five openminded farmers, who spread around an awareness of this issue, while others are the farmers who are influenced by the priest or dependent on him [...] The second bloc consists of old-Rusyns [...] [But] the majority of the people are simply indifferent, they call themselves 'Rusnacy' and they don't belong to any camp.

Second, the area became a playground of violent religious conflicts, which were strictly connected to the clashes between different political fractions. The most consequential one was the competition over the faithful between the Greek Catholic and the Orthodox Church. A rather unexpected outcome of that conflict was the growth of different Protestant communities and the Jehovah Witnesses' movement. Both reached Uście Gorlickie through returning migrants from the US and were joined by many locals who were tired of the fights within Eastern Christian churches (Krochmal 1997:141-2). According to a Pentecostal inhabitant:

In the interwar period, there was a continuous struggle here. The Orthodox Church attempted to win influence over the Greek Catholics. And suddenly, in the 1930s, there begins to grow a dynamic, well-functioning Protestant church which attacks them both [...] It was a dirty struggle, in the prewar period, they would stop at nothing.

What is important about this statement is the fact that it challenges an idyllic view of the prewar time, which is present not only in people's memories but even in the scholarly works on the subject. Additionally, it is important to add that the conflicts on the local ground were actually far from local; many of them, and in the main the one between the Orthodox and the Greek Catholic Church, were instrumentalized by the Polish state and the Roman Catholic Church. Depending on the circumstances, they either fought against Ukrainian (Greek Catholic) or Russian (Orthodox) influences.

Generally, the aim of the interwar Polish authorities was to reinforce the Lemko-Rusyns' regional identity which was supposed to facilitate their integration into the Polish society and prevent Ukrainian influences. It was only after the Second World War that the policies moved in the opposite direction. As the new communist authorities promoted a view of "Poland for Poles" and looked for justification for ethnic cleansings and resettlements, they argued about the strong connection between Lemkos and Ukrainians. These arguments did not only relate to the presumed support of Lemkos for the UPA during and in the aftermath of the Second World War, ${ }^{5}$ but presented Lemkos as a dis-

5 The Lemkos' virtual lack of support for the UPA is shown not only by scholars (Motyka 2002; Horbal 2002), but also by reports of UPA members (Motyka 1999: 297-99). 
loyal and opportunistic population, which did not have much to do with the Polish nation. Crucially, a remarkable role in both these processes of manipulating the Lemko-Rusyns identity was played by scholars, mainly ethnographers, who were expected to provide "proper" evidence and, according to current circumstances and demands, present Lemkos either as Poles to be or as fully Ukrainian (see Hann 2006:193-4; Misiło 2002: 81).

By expulsing Lemkos, the new communist authorities completed the work commenced by the war occupants-massive repopulation carried by Soviets as well as forced recruitment to work camps by Nazis—and altered completely the area of Uście Gorlickie. After Operation Vistula and the resettlement of the last Lemkos inhabitants to the "recovered territories," Polish Roman Catholics were given the abandoned lands and houses. In the late 1950s, some Lemko families managed to return. They built new houses or repurchased their old farms. The diversification of ethnic landscape was accompanied by complex religious changes. The Greek Catholic Church being banned, Lemkos had to choose between participation in Orthodox or Roman Catholic services. They faced a similar choice in the late 1980s when the Greek Catholic Church was restored. Despite a period of violent persecution in the early 1950s, Jehovah's Witnesses and Pentecostal communities maintained their creed and continued religious practices. Internal conflicts as well as Adventists' missionary work led to a series of division within Protestant communities.

The transformation of 1989 brought many important changes into minorities' lives. The new system provided the possibility to establish associations, organize cultural activities, and promote the minorities' heritage. New legislation regarding the teaching of minority languages and religion at school brought further opportunities. However, a vast majority of the new policies concern "culture" (broadly understood) and do not translate into improvements in other areas. Furthermore, it is important to remember the role of the Polish state in shaping the ethnic-religious landscape in Uście (as elsewhere in Poland). In the case of religious life, it mainly regards the prioritization of the Roman Catholic Church, which indirectly led to the conflicts between the Greek Catholic and the Orthodox community, as well as the mainstream discourse on "sects," which affects local Jehovah's Witnesses and Protestant communities (cf. Zielińska 2006).

In the case of ethnic groups' rights, the state decisions brought further complication into Ukrainian-Lemko relations. I have mentioned before that in the interwar period the Rusyn population was defined as "Lemko" in order distinguish it from the Ukrainians; in the communist period, the Lemkos were considered "Ukrainian" in order to justify their resettlement; and the new legislation from $2005^{6}$ defined the Lemkos as an "ethnic minority," in contrast to Ukrainians who are defined as a "national minority." The Ukrainians objected to this decision, perceiving it as interference in internal Ukrainian-Lemko matters and settling the debate about Lemko identity, while many Lemkos welcomed it (Kirpsza 2008:20). Certainly, a solution satisfying both sides was impossible to reach, but the decision needs to be seen as the consequence of long-term processes.

Today, the commune is inhabited by seven religious communities: Roman Catholics, Greek Catholic, Orthodox, Pentecostals, Jehovah's Witnesses, Adventists, and Buddhists. Being proud of the local diversity, local people tend to claim that there are many more creeds; among "usual" candidates there are Baptists, Hindu, and Atheists. Although local people's "hints" at the presence of yet other religious communities are usually mistaken, they are very important for the understanding of "pluralism from below." Broadly consid-

\footnotetext{
6 "Act of 6 January 2005 on national and ethnic minorities and on the regional languages" (Ustawa o mniejszościach narodowych i etnicznych oraz o języku regionalnym).
} 
ered, the local religious-ethnic mosaic is very complex and even providing a purely analytical presentation is a hard task. If I start by saying that there are two main ethnic groups, the Poles and the Lemkos, I need to clarify immediately that some Lemkos consider themselves to be Ukrainian, while others claim to be both Lemko and Ukrainian and yet others stress their adherence to the transnational Rusyn community. Nevertheless, taking "Poles" and "Lemkos" as two ideal types, it is possible to describe the local mosaic as follows: in general, the Lemkos belong to either the Greek Catholic or the Orthodox Church; both churches are perceived by them and by others as their "national" churches. However, among the Lemkos are also numerous Pentecostals and some Adventists and Jehovah's Witnesses. While the members of the former (Pentecostals) tend to highlight their Lemko identity, the latter rarely do so and if they do, it is seen as diverging from their creed (Jehovah's Witnesses). As to the Poles, the majority belong to the Roman Catholic Church. Still, Poles are also members of all the other religious congregations: the Pentecostals, Jehovah's Witnesses, Adventists, and Buddhists. There are also many Poles who joined the Orthodox or the Greek Catholic Church because of family ties and this is even more common among the Lemkos who joined the Roman Catholic Church. Last but not least, the above list needs to be supplemented by a civic identity, i.e. the identity of being Polish understood in political and not ethnic terms.

A historical analysis of the dynamics of pluralism in Uście reveals several recurring patterns: the role of the state in shaping the interreligious and interethnic relations; the relation between confessional and ethnic identities; the intellectuals' and activists' engagement vis-à-vis the population indifference; and the interplay of positive and negative experiences of pluralism. In the following, I demonstrate that the very same phenomena can be observed today.

Pluralism, despite...?

Having provided some theoretical reflections and a short historical overview, let's go back to the park in Wysowa Zdrój and see how past and present pluralism is displayed there.

The Wysowa's park was constructed in the mid-19 $9^{\text {th }} \mathrm{C}$. by Polish aristocrats who discovered the economic potential of mineral waters and decided on building a spa, which turned into a very successful and widely recognized investment. The development of the health resort was interrupted by the First World War. Partly renewed in the interwar period, Wysowa's health industry went into decline during the next world conflict. In People's Poland, the health resort was nationalized and equipped with sanatoria and a specialist hospital. However, it was only after 1989 that the authorities made an attempt to bring back the past splendor on the health resort, paying special attention to the park area which was supposed to become a prominent symbol of the entire, increasingly tourism-oriented, commune. Apart from beautiful ancient trees, tranquil alleys and the above mentioned rebuilt pump room, the park contains a few historic villas which today function as pensions.

According to my oldest informants, a part of the park used to belong to Jews who ran a store and an inn there. Although all Wysowa's Jews perished in concentration camps during the war and no Jews live there today, it is important to start the exploration of local pluralism precisely with the "Jewish question." Analyzing my research material, I referred to Jews as an "invisible minority" the image of which is activated in certain 
contexts. Importantly, the memories of Jews are recalled by both Lemkos who lived in Wysowa before the war and by Poles who settled in the area after Operation Vistula and brought their memories of Jews from different parts of Poland. The first group approaches Jews in two different ways: they condemn those people who made money out of Jewish tragedy (for instance, by using their houses after Jews were taken to the concentration camp) and at the same time they speak about the Polish state's preferential treatment of Jews, who nowadays get back their properties while Lemkos wait in vain for material compensation for "Operation Vistula." In contrast, Poles' comments on Jews regard some stereotypical characteristics such as flair for trade or attachment to money. What I noticed frequently was the use of certain wordings and grammatical constructions which were used to describe Jews. These were expression such as "for a Jew" ("honest for a Jew"), "though" ("honest though a Jew"), "even if" ("even if he is a Jew...") or "despite" ("despite being a Jew, he is a good person").?

I got used to such comments talking to inhabitants as well as eavesdropping on tourists' conversations while sitting in the park. In addition, I realized that the way people talk about Jews characterized their opinions about different "others", too. A person who excelled in this process was Ms Tekla - the chief guide of the commune, who often visits the park with groups of the sanatoria's visitors. The task of Ms Tekla is to present tourists with the multicultural heritage of the region, and thus she shows tourists Eastern Christian wooden churches, old Lemko buildings and unique cemeteries from the First World War. Ms Tekla is a very cheerful and talkative person, and her touristic routs are accompanied by vivid stories. The question is: the stories of what?

Having seen Ms Tekla with tourist groups and having heard about her from numerous inhabitants, I decided to take part in one of her lectures. Her story of local multiculturalism was the story of Roman Catholic bishops and Polish aristocrats, who owned the territory and led to its development. She said few words about Rusyn colonization of the area and kept silence on the postwar violent resettlements, but she paid a lot of attention to the development of the sanatoria and spa. Since I did not participate in her lectures or tours regularly, I cannot assert that she never paid more attention to the question of the Lemko (or other minorities') situation. However, the way she presented Poles and Lemkos relations during the meeting I attended exemplifies a scheme in which majority-minority relations are often framed in the Polish historical discourse. According to this scheme, Poles (nobles, clergy, and intelligentsia) constitute an enlightened, tolerant and devoted majority, while minority communities are first and foremost inscribed to the sphere of local folklore and, crucially, representatives of a different "culture."

The way Ms Tekla describes the pluralistic character of the area is very telling, too. Asked about the interreligious and interethnic relations, she answered that "they are exemplary" and explained: "We permit the Orthodox to work with us." Describing the places that she intended to show to a tourists' group, she observed that "the shrine should be respected even though it is Orthodox." And when I enquired whom I should talk to in order to learn something about the region, she provided me with a list which started with a Polish aristocrat who had recently moved to Wysowa and which ended with representatives of non-Catholic religious communities. According to Ms Tekla, they were worth talking to despite being Buddhist or Pentecostal. And thus, her comments account for above reflections on hierarchical pluralism: the fact that while permitting or even ac-

7 It is worth adding that the very same expressions were used by a guide in the synagogue in Bobowa (in the past a notable center of Hasidism), which I visited with a group of Greek Catholic youth. 
knowledging diversity, it is made clear who is the one to permit and recognize and who is the one to ask for permission and strive for recognition. Ms Tekla's use of "we" constitutes an implicit reference to the Polish Roman Catholic majority, the dominance of which is taken for granted and simply "natural."

One of the places Ms Tekla always visits with her groups is the pump room, situated in the center of the park. The person in charge of the pump room is Tadek, a garrulous and very friendly man in his mid-forties. Tadek is very eager to speak to anyone who drops by for a glass of water. He recounts for spa-guests the history of Wysowa and entertains them with funny stories. The way he talks as well as his rich repertoire of body language makes him quite a character.

When I visited Tadek for the first time and told him about my research on religious pluralism, he poured me a glass of smelly mineral water and immediately began to provide me with all sorts of information. He told me that he was a Pentecostal and that I should get to know his congregation, come for a service and meet with the congregation's representatives. He emphasized that coming to one of the services was particularly important since it was very different from the Catholic mass I was used to. When I interrupted him and asked why he assumed that I am a member of the Roman Catholic Church, he gave me a look that suggested that he did not really understand the sense of my question. He continued, and after he repeated a similar suggestion about me being a Roman Catholic, I interrupted. "Why do you assume I am a Roman Catholic?" I asked. Again, he looked at me surprised and said: "Well, I hope you are not an atheist!" Then he said that "the faith is one, there are several confessions," what supposedly meant that Roman Catholics are not that far from Pentecostals-what matters is the belief in God.

I need to make a small digression and add that contrary to Tadek, who was so surprised by my question, I was not at all surprised by his claim about my religious belonging. The assumption about my Roman Catholic background shaped many of encounters with my informants and our exchanges on the subject resembled the one I had with Tadek. People-among them non-Catholic Poles and Roman Catholic Lemkos-would often say that "it is normal to be Roman Catholic in Poland" or go as far as to ask: "what else than a Catholic can you be in Poland?" Interestingly, the only person who questioned my belonging to the Roman Catholic Church was a devout Roman Catholic woman, who was astonished at my ignorance of certain Catholic festivities. Referring once again to the earlier discussion of hierarchical pluralism, it is important to remember that the power of the norm (in this context, the norm of "Pole-Catholic") lies in the fact it leads to the process of self-exclusion. Confronted with the norm, people exclude themselves from the Polish national community by highlighting what is considered normal and proper.

Tadek and I continued the discussion, or rather he continued his vivid description of the Pentecostal community. He told me about the past persecutions and that the life today is good precisely because they are not persecuted. He said that the relations between different religious communities were good. Then he stopped for a moment and added: "Tolerance is fashionable today and folklore is a useful promotional tool." As a person working in the tourist sector, he was conscious of that aspect of local "multicultural" policies.

I am not the only person with whom Tadek shares the knowledge and experiences of the Pentecostal community. He claims that he never aims to convert anyone and that he just speaks about local diversity. And yet, his way of promotion of local diversity does not seem to be generally accepted. One day, two elderly visitors dropped by for a glass of mineral water and stopped to converse with Tadek. They stayed quite a while and 
Tadek was very proud that they got so interested in his stories. He told them that a part of Wysowa, so-called Huta Wysowska, is inhabited by many Pentecostals. Indeed, not only do many Pentecostals live there today but this part of the village was the place of first Pentecostal gatherings and prayers before the war. The conversation was overheard by a commune's representative and-as she herself told me, referring to the situation nervously — she quickly ran to the "group of frightened ladies" and "reassured them" that Pentecostals were not that numerous. "They were so scared!" she emphasized. She was deeply concerned that Tadek's stories may have a damaging effect on the image of the (multicultural!) commune. Tadek's version differed. He described the "frightened ladies" as "intrigued" and claimed that were very interested in his story since they had not known anything about the presence of different religious communities in the area.

The reaction of the commune's representative is very revealing about the way diversity is perceived by many representatives of the majority. What needs to be highlighted once again is the "taken-for-grantedness" of the Polish-Catholic norm and the assumption of certain attitudes towards "others," such as the fact that information about numerous "others" might scare off people. Briefly speaking, the diversity is "fine" but the limits are set. So it is a certain representation of minorities: they are no more than an "addition" to the local landscape. Such a perception of minorities was reflected in other comments of the local authorities with whom I spoke. When I inquired into the local "management of diversity," they would often stress that minorities "demand" something, for example the right to organize non-Catholic religious teaching. In the case of the majority, however, the very same issue (religious teaching) was not perceived as a demand but as a natural "entitlement."

In order to illuminate this process, let me turn once again to the pump room and Wysowa's park. Tadek's more or less successful promotion of diversity is not the only way diversity is being talked about and represented in the area. In order to enrich the calendar of the cultural events and preserve regional heritage, the commune's authorities and diverse local activists have undertaken different initiatives which display the richness of Lemko traditions. These are, for example, the concerts of Orthodox Church music and Lemko choirs' performances. The wooden pump room, which bares resemblances with local wooden churches, provides a very good setting for such performances.

Encouraged by the example of Lemko concerts, the local Pentecostal community asked the local government for permission to organize a performance of Pentecostal songs on the bandstand situated in the vicinity of the pump room. The local government objected and defended the decision by stating that Poland is a secular country and the public sphere must be free of religious content. When one of the Pentecostals noted that the Roman Catholic Corpus Christi procession takes place in the public sphere too, he heard that Corpus Christi is a part of "tradition" and that it is something "normal." Eventually, after long negotiations, the authorities granted the congregation permission to organize a concert but forbade the organizers to speak during the performance. They strictly controlled the entire course of the preparations, interfering even in the appearance of the posters. Disheartened by the difficulties, the Pentecostals have not tried to organize any other public performances. What is organized every summer nearby the bandstand, however, is the "Folkloric fair" which gathers artisans, circles of rural housewives, food producers, and farmers who offer tourists and inhabitants local traditions and products: objects and groceries which have been indeed present in the region for decades and those which have been recently re-invented or re-branded for the purpose of present-day regional promotion. 
The difficulties faced by the Pentecostal community are perhaps the most revealing evidence of the double-edged character of "multicultural" policies. It accounts for a situation in which in theory everyone has equal rights but in practice some individuals or groups are discriminated against and in which the means of discrimination is the reference to equal rights (in this case: the neutrality of the public sphere). The reason why discrimination takes places is the fact that the Roman Catholic creed is "more equal among equals;" their presence in the public sphere does not count as presence because it is a part of "tradition," as such it "goes without saying" and it is perceived as something "normal." In other words, while the presence of minority communities is visible (and disturbing for many), the presence of Roman Catholic rituals or symbols is supposed to be invisible, as it is a "natural" part of the local landscape.

The above examples permit us to go a step further and ask why not only Roman Catholic Poles are "more equal" than others, but also why some minorities are "more equal" than others. This question is a complicated one as it touches upon the complex relation between religious and ethnic identities. The emphasis on Lemko heritage means both the acknowledgment of Greek Catholic and Orthodox heritage and a broadly understood culture (culinary traditions, architecture, music) of the Rusyn population which has inhabited the region for centuries. And thus, one possible explanation for the acknowledgement (albeit limited) ${ }^{8}$ of Lemkos in the public sphere is the "post-1989 turn" and "historical justice." The other potential argument relates to statistics, namely the fact that Orthodox and Greek Catholics are the most numerous minority communities in the area. Yet another possible reason is the fact that the combination of ethnic and religious factors makes, at least in some contexts, the articulation of group interests easier. However, having in mind Tadek's words about "tolerance" and "folklore," as well as earlier reflections on multiculturalism, it is possible to come up with yet another explanation. If the diversity is supposed to "sell well" and attract visitors, then the Lemko ethnic-religious culture constitutes a much more suitable candidate for the icon of local diversity than, say, Jehovah's Witnesses or Pentecostals. In other words, a minority group is more easily accepted when transformed into a "culture."

The last point brings us back to the earlier discussion of hierarchical pluralism and multiculturalism. It reminds us that hierarchical pluralism entails the acceptance of diversity but that the very act of accepting displays who has the power to accept and who seeks to be accepted. And, it accounts for a pitfall of multiculturalism, namely the idea of the recognition of different "cultures" as a sole means of building a more egalitarian society. However, in order to make the picture complete it is necessary to contrast this "pluralism from above" with its grassroots counterpart.

\section{Pluralism from below}

The observations presented above regarding the majority-minority relations and the outcomes of "multiculturalist" policies may at first glance confirm Long's and Bouma's (2009) contention that some settings might be plural yet still lack pluralism. The ironic commentary quoted in my introductory remark ("Well, we have multiculturalism today!") seems to account for this statement, too. However, the fact that local people distance

\footnotetext{
8 A good example of this fact are Polish inhabitants protests against the introduction of double-naming (see Pasieka forth.).
} 
themselves from "multiculturalism," which they often perceive as a foreign and imposed idea, does not mean that they reject pluralism as such. Quite the contrary, the way local people understand, experience and talk about diversity enables us, in my view, to rethink the very idea of pluralism.

While describing the dynamics of local life, my informants often reached for the notion of "ecumenism" (ekumenizm, ekumenia). The way they used the word did not necessarily correlate with the actual meaning of "ecumenism" (i.e., the initiatives aimed at cooperation of different Christian denominations). Rather, most of the villagers used the notion of ecumenism to denote the multiplicity of religion and (desired) attitudes towards diversity. Depending on the speaker's assessment of current developments, this notion could be quoted proudly, affirmatively, bitterly, critically or even cynically. This does not mean, however, that some people viewed it positively and others negatively, or that some placed hope in it while others were completely disillusioned. In the local understanding, "ecumenism" is not "either-or" — "good" or "bad"—but it is both. Approaching local diversity in this way, people demonstrate their awareness that the multireligious coexistence is marked and needs to be evaluated by positive and negative experiences. Additionally, they demonstrate their awareness that only such an approach permits the local community to "carry on." The following extract from an interview with a Pentecostal pastor well illustrates this point:

Pastor: (...) And as to "ecumenism", at the beginning of the $21^{\text {st }} \mathrm{c}$. journalists would come constantly here. One day, a team of journalists from Gazeta Krakowska came and here... [they stopped] an elderly lady (babinka) from Hańczowa ... [and told her]: "Ma'am, it is really great here, with all these Lemkos, and all these... these... these twelve confessions you've got here. You've got such a great ecumenism here!" [The old lady answered:] "Indeed, ma'am, we have ecumenism. We do have it! Over there, at the cemetery - one lies next to another...."

\section{Agnieszka: (laughing)}

Pastor: She really made a point, and another old lady standing next to her added: "We also have ecumenism at the local petrol station. Everyone goes to buy petrol there" (...) And this is the way people perceive it... people really don't see problems, while journalists look for sensation, [they ask:] "what kind of recipes you have that ... together... confessions live." Well, we live side by side, we have to, we have to strive to achieve an agreement, to look for those... positive relations. And the fact that one goes to one church and the other to a different church is a completely, completely... not a priority at all. If this was the most important thing, then we would have problems and conflicts."

In his description of "ecumenism," the pastor points out two important things. First, he emphasizes the role of "outsiders" in shaping local pluralism. In the quoted example journalists wonder about the possibility of coexistence of different religious creeds and perceive it as something extraordinary, while the pastor stresses that belonging to a church and ethnic background are not the most important factors that influence social relations. The contrast between the journalists' and the inhabitants' approach well illustrates a widespread tendency to prioritize ethnic/religious aspects in the studies of plural settings, as if no other factors - such as political views, neighborly and family bonds, professional relations-entered into play. By saying this, I do not aim to question the specificity of Uście Gorlickie, but to point out that the amusement accompanying the question "how do you manage to live together?" brings along the suggestion that "there must be" conflicts and tensions. A similar assumption characterizes activities and discourses of other sorts of 
"outsiders." An exemplary case here may be the "workshop for tolerance" which was organized for local people by a woman who had recently settled in the area and managed to organize the workshop in cooperation with a Warsaw NGO. When I asked a teacher who participated in the workshop about her opinion about it, she answered, annoyed: "I do not have anything against such workshops. But I have a feeling that we live fine here, until somebody comes and tells us we need to learn to be tolerant!"

Certainly, the question is what it means to live "fine." This query leads to the second point indicated by the pastor, namely the fact that local people need to look for "positive relations." In my view, this statement proves the awareness of the tensions and contradictions that characterize local coexistence-the fact that it is built on positive and negatives experiences. Minority communities are aware that "living fine" means living in the accordance with the norms established by the majority, and that the taken-forgrantedness of the majority's dominance often leads to a situation in which discrimination against the minorities cannot be comprehended by the majority (for their attempts to do something are considered "demands" and not "entitlements"). And yet, many of them are aware that dwelling on bad experiences does not bring far and thus they attempt to carry on despite bitter and discouraging experiences.

Undoubtedly, such an approach can be interpreted as a sign of resignation or a tacit acceptance of status quo. Likewise, it can be read as a contention that some improvements have been made and one should be happy with them ("We are not persecuted," was the observation of Tadek). However, all these views reflect the majority's ones ("Be happy with what you've got") and I believe that presenting them as the only explanations means simplifying the local history and the picture of social relations. In order to comprehend local pluralism, it is important to confront idyllic stories about the prewar paradise and accounts on conflicts and squabbles and to take into account the then interplay of external and local factors in shaping local pluralism. And, in order to comprehend local pluralism, it is important to remember that people do not enter into social relations as representatives of certain ethnic group or religious congregation (or as icons of a "culture"), but as neighbors, friends, workmates, or football players. Such an interpretation permits us to say that local people's "recipe" for a good coexistence is using common experiences to push hierarchical pluralism as close as possible towards the pole of pluralism, while being aware that it can easily move back to the pole of hierarchy.

RETHINKING PLURALISM

Having provided a theoretical overview and discussed my ethnographic material, I would like to return to the question of the meaningfulness of the concept of pluralism in the Polish context. Giving a positive answer to this question, I argue that not only does my case study account for religious pluralism but it exemplifies the very contradictions and tensions that characterize pluralism (as they characterize every "-ism").

First, the analysis of the multireligious commune demonstrates that pluralism occurs at different levels and it thus seems pointless to speak about a society having (or not having) pluralism; one can study engagement at the level of state policies, civil society institutions or neighborly relations. These different dimensions do not necessarily match and some have argued that the failures of pluralism are often a result of incongruences 
between different levels. The best example of this fact is the local people's awareness of different possible constellations of religious and ethnic identities and the simultaneous conviction of the "normality" and the "obviousness" of the Polish-Catholic connection, which is enforced by different mainstream discourses and policies. At the same time, some top-down policies which are supposed to reinforce "multiculturalism" are viewed with suspicion or even rejected. Furthermore, it is important to add that a study of diversity means the necessity of taking into account the experiences of diverse communities and individuals. For the purpose of this article, I referred mainly to the Pentecostal community and to Greek Catholic and Orthodox Lemkos, whose experiences, in my view, account for many salient problems. However, this choice should not lead to overlooking important differences between minority communities, for example those resulting from religious beliefs and rituals. An illustration of this point may be the fact that the similarity of Eastern Christian practices to the Roman Catholic ones makes them more easily acceptable by the Roman Catholic majority (in comparison to Protestants or Jehovah's Witnesses). Yet another example here may be the perception of faults and sins in different religious traditions. Remarking upon the difficult relations with the majority, Protestant communities and Jehovah's Witnesses were very reluctant to judge others and emphasized that this is God's task, while Orthodox or Greek Catholics often did not mince their words. Obviously, one should not generalize from these observations other than to recognize that individuals' approaches to pluralism may vary significantly, they may shift over time and they often depend on the given context. Common experiences in my fieldwork were interviews with minority representatives, who complained of the discrimination from the Polish state or local Roman Catholics. Still, after a series of such complaints they would often start to discriminate against Jehovah's Witnesses (who arguably are the least respected religious community) or express their contentment that no Muslims live in the area. Such comments remind us of the multiple hierarchies that may characterize local pluralism, and they indicate the role of external factors in shaping it. ${ }^{9}$

Second, scholars' emphasis on the "engagement" and "commitment" that pluralism includes should not obscure the fact that both the understanding and the outcomes of such endeavors are far from obvious. For pluralism, understood as a positive response to diversity, does not preclude either negotiations or debates about "how far" diversity should be permitted to go and acknowledged or where the limits should be set. Examples from my fieldwork demonstrate that an open approval of pluralism may result in the reinforcement of inequalities through the reification of religious differences and social hierarchy. Importantly, social actors may-consciously or unconsciously-put this mechanism into practice. Many people who believe themselves to be ardent adherents of diversity end up questioning pluralism, in discourse or practice, or putting it into a frame they find acceptable. In reference to my earlier examples one may observe that the local government employees or the local guide undoubtedly believe themselves to be the agents of pluralism. After all, they strive to meet minorities' demands and they spread the knowledge about local multiculturalism. The fact that at the same time they reproduce existing hierarchies does not always occur to them-and it is precisely this unconscious, unnoticed aspect which makes "symbolic violence" so powerful.

And third, while rethinking pluralism, it is important to reflect on what kind of people and institutions have a say in promoting (and foreclosing) pluralism. Discussions of religious diversity and interreligious dialogue often assume that religious leaders should

-...

9 I mean here, for example, the mainstream discourse on "sects." 
be the main agents in this process. Notwithstanding their importance, it is important to highlight the role of secular authorities in regulating pluralism. The above analysis demonstrates the manifold ways in which the state shapes religious pluralism; it does so not only by deciding on legislation but also through various discourses and policies which, in theory, do not relate directly to the religious sphere. An issue of particular importance in this context is the various "cultural policies," which, by determining allocation of funds or defining what the country's cultural heritage is, may prioritize certain religious traditions and institutions. The Polish state's attitude towards Catholicism and the Catholic Church provides numerous examples of this trend. Crucially, it seems that the state often acts in the name of the Catholic Church, or defends its position, without even being "asked" to do so. This fact says a lot about the picture of church-state relations in Poland, but it also demonstrates the role of religion as culture in shaping pluralism, and in this way-yet another face of "Polish multiculturalism." Last but not least, the account on the shifting policies towards Lemko-Ukrainian identity has shown that observations regarding the state's importance may well apply to the ethnic diversity. Additionally, that account has also proven the role of scholars in molding the discourse on diversity and even in establishing what counts as diversity and what does not.

CONCLUSIONS

My paper attempted to problematize the idea of pluralism by demonstrating its doubleedged character. I argued for the necessity of focusing on the contradictions and tensions that characterize pluralism and I suggested that the discussion of pluralism should be linked with the debate about multiculturalism. The two points led to the discussion of diversity and inequalities, which evinced that discrimination and hierarchy are intrinsic aspects of social relations in plural settings. I therefore suggested that the fact that the outcomes of pluralism are not only far from obvious but often contrary to what pluralism purports to achieve, should not come as surprising. What, instead, should be inquired into is the very process of the reproduction of inequalities within plural settings. That is why, the problem I aimed to address was the question of how vertical forms of differentiation are produced and made to come across as inherent, that is: how pluralism becomes hierarchical.

Drawing on my ethnographic material from a multireligious and multiethnic area in rural Poland, I discussed several means by which pluralism becomes hierarchical. First of all, I argued that the foundation of hierarchical pluralism is the treatment of certain aspects of the Catholic religion-religious identity, tradition, symbols, shrines-as something "normal" and "natural," as undisputable and taken for granted element of the social order. Due to a strong connection between ethnic and religious identities, the idea of "Pole-Catholic" functions as a binding norm, is deeply internalized by minorities and leads to their self-exclusion from the national community. Secondly, I demonstrated that pluralism often constitutes the coverage of inequalities and it leads to a situation in which under claims of equality there are factual inequalities. The reason for that is the fact that despite the parity in terms of law and civic guarantees, people experience exclusion due to different forms of power-which are often invisible, hard to "measure" and situated in the least "suspicious" spheres (Bourdieu 1977, 1992). Thirdly, I suggested that understanding religious pluralism requires a careful consideration of the role of the different secular agents in shaping it as well as the importance of religion as culture. 
Tying these issues together, it is possible to observe that a fundamental aspect, which permits us to understand the way pluralism functions as both discourse and social practice, is pluralism's power to naturalize. What is crucial here is the fact that not only some identities/norm/beliefs become perceived as "normal," but that the configuration between different identities, beliefs or traditions becomes taken-for-granted, too. For instance, the discourse of religious pluralism may result in making some religious encounters and some religions normal and natural (Klassen and Bender 2010:3); in other words, pluralism may result in reifying both religious difference and its constellation. Similarly, the idea of multiculturalism, by inscribing cultural identities "for good" and defining positions of "cultural minorities" vis-à-vis the majority, makes the view of the world as a collection of (hierarchically ordered) cultures appear normal and natural.

Although my article draws on research in a rather idiosyncratic Polish locality, I believe that reflections on pluralism speak to a variety of socio-political contexts. Taking into account a broader Polish context, it is important to observe that the normativity of the "Polish-Catholic" bond does not only affect religious others, but also numerous individuals and groups (among them Catholics) who disagree with or feel they do not fit within this model. After all, pluralism does not only entail the presence of different religious groups, but also an acknowledgement of the plurality of standpoints and beliefs. ${ }^{10}$ Moving beyond and looking at the religious landscape in certain Western countries, it is also possible to observe the continuous importance of Catholicism and other Christian denominations as a point of reference, as a norm to refer to, even by the countries and by people who promote secularist ideology, are proud of "laicitè" and church-state division. Examples from France, Italy or Quebec illustrate the power and the normativity of the discourse, which imposes religion as "tradition" or "culture" (e.g. Bowen 2009; Pace 2007), demonstrate societies' problematic relation with their own tradition and their own religious pasts (Zubrzycki 2013), and problematize the role of secular and religious authorities in accommodating pluralism (e.g. Fetzer and Soper 2005).

First and foremost, however, I hope that my article makes evident yet another generally valid claim - the fact that a scholarly anthropological contribution cannot entail relegating what informants say to "ethnography" and what researchers say to "theory" (Reed-Danahay 1993: 221). Giving voice to my informants and presenting their-sometimes ironic, sometimes funny, sometimes bitter, but always thoughtful and drawn from experience-understandings of pluralism, I aimed to show how local knowledge permits us to rethink pluralism. In the main, it permits us to understand that a seemingly contradictory notion of "hierarchical pluralism" in not an oxymoron but a tautology.

\section{BIBLIOGRAPHY}

Berghe, P.L. 1973. Pluralism. In: J.J. Honigmann (ed.) Handbook of social and cultural anthropology. Chicago, III.: Rand McNally, pp. 959-978.

Bourdieu, P. 1971a. Genèse et structure du champ religieux. Revue française de sociologie 12(3): 295-334.

\footnotetext{
10 I contend that the prominence of the discourse on multiculturalism (and not on pluralism) in Poland makes this issue less obvious.
} 
—. 1971b. Une Interpretation De La Theorie De La Religion Selon Max Weber. European Journal of Sociology 12(1): 3-21.

-. 1977. Outline of a theory of practice. Cambridge [u.a.]: Cambridge University Press.

-. 1992. The logic of practice. Stanford, Calif.: Stanford University Press.

Bourdieu, P. and L.J.D. Wacquant. 1994. An invitation to reflexive sociology. Chicago [u.a.]: University of Chicago Press.

Bourdieu, P. and J.-C. Passeron. 2000. Reproduction in education, society and culture. London [u.a.]: Sage.

Bowen, J. 2009. Can Islam be French? Princeton: Princeton University Press.

Burszta, W. 1997. Wielokulturowość. Pytania pierwsze. In: M. Kempny, A. Łapciak, S. Łodziński (eds.) U progu wielokulturowości. Nowe oblicza społeczeństwa polskiego, Warszawa: Oficyna Naukowa, pp. 23-31.

—. 2005. Antropologia kultury. Warszawa: Wyd. Zysk i S-ka.

Despres, L.A. 1968. Anthropological Theory, Cultural Pluralism, and the Study of Complex Societies [and Comments and Reply]. Current Anthropology 9(1): 3-26.

Dumont, L. 1980. Homo hierarchicus. Chicago [u.a.]: University of Chicago Press.

Eck, D. 2006. From Diversity to Pluralism. http://pluralism.org/pages/pluralism/essays/ from_diversity_to_pluralism (Accessed: 1.04.2013).

Eller, J.D. 1997. Anti-anti-multiculturalism. American Anthropologist 99(2): 249-256.

Eriksen, T.H. 2006. Diversity versus difference. In: R. Rottenburg, B. Schnepel and S. Shimada (eds.) The making and unmaking of differences. Bielefeld: transcript, pp. 13-26.

Fabian, J. 1985. Religious pluralism: An ethnographic approach. In: W. van Binsbergen and M. Schoffeleers (eds.) Theoretical explorations in African religion. London [u.a.]: $\mathrm{KPI}, \mathrm{pp} .138-163$.

Fetzer, J.S. and J.C. Soper 2005. Muslims and the State in Britain, France, and Germany. Cambridge: Cambridge University Press.

Furnivall, J.S. 1948. Colonial Policy and Practice: A Comparative Study of Burma and Netherlands India. Cambridge: Cambridge University Press.

Furseth, I. 2009. Religion in the works of Habermas, Bourdieu, and Foucault. In: P.B. Clarke (ed.) The Oxford handbook of the sociology of religion. Oxford: Oxford University Press, pp. 98-115.

Hann, C. 2006. Peripheral populations and the dilemmas of multiculturalism. In: B. Horbal (ed.) The Carpatho-Rusyns and their neighbors. Fairafax, VA: Eastern Christian Publications, pp. 185-202.

Harzig, C. and D. Juteau. 2003. Introduction: recasting Canadian and European history in a pluralist perspective. In: C. Harzig and D. Juteau (eds.) The social construction of diversity. New York: Berghahn, pp. 1-12.

Horbal, B. 2002. The Ukrainian insurgent army in the Lemko region. In: P. Best (ed.) The Lemko Region, 1939-1947. New Haven, Ct.: Carpatho-Slavic Studies Group, pp. 171-182.

Iteanu, A. 2009. Hierarchy and power. In: K.M. Rio and O.H. Smedal (eds.) Hierarchy: persistence and transformation in social formations. New York [u.a.]: Berghahn Books, pp. 331-348.

Juteau, D. 2003. Canada. In: C. Harzig and D. Juteau (eds.) The social construction of diversity. New York [u.a.]: Berghahn Books, pp. 249-261.

Kirpsza Adam, 2008, Mniejszości narodowe i etniczne w prawie międzynarodowym i polskim. In: J. Kihl, J. Piecha, M. Galon, A. Gorgosz and T. Pawłuszko (ed.) Mniejszości narodowe i etniczne, Wydawnictwo AT Group S.A., Kraków. 
Klassen P.E. and C. Bender. 2010. Introduction. In: C. Bender and P.E. Klassen (eds.) After pluralism: reimagining religious engagement. New York: Columbia University Press, pp. 1-28.

Krochmal, A. 1997. Specyfika stosunków wyznaniowych na Łemkowszczyźnie w XX w. In: A. Zięba (ed.) Łemkowie i temkoznawstwo w Polsce. Kraków: Polska Akademia Umiejętności, pp. 135-143.

Kuper, L. and M.G. Smith. 1971. Pluralism in Africa. Berkeley [u.a.]: University of California Press.

Ling, R. and G.D. Bouma. 2009. Religious diversity. In: P.B. Clarke (ed.) The Oxford handbook of the sociology of religion. Oxford: Oxford University Press, pp. 507-522.

Misito, E. 2002. Polish pre-war legislation in regard to the post-war deportation of the Lemkos (1944-1946). In: P. Best (ed.) The Lemko Region, 1939-1947. New Haven, Ct.: Carpatho-Slavic Studies Group, pp. 75-82.

Motyka, G. 1999. Tak było w Bieszczadach: walki polsko-ukraińskie 1943-1948. Warszawa: Volumen.

—. 2002. The UPA in the Lemko region. In: P. Best (ed.) The Lemko Region, 1939-1947. New Haven, Ct.: Carpatho-Slavic Studies Group, pp. 131-136.

—. 2011. Od rzezi wołyńskiej do Akcji "Wisła". Konflikt polsko-ukraiński 1943-1947. Kraków: Wydawnictwo Literackie.

Pace, E. 2007. A peculiar pluralism. Journal of Modern Italian Studies 12(1): 86-100.

Pasek, Z. 2006. State and local governments policies towards new religious movements in Poland, 1989-2004. In: I. Borowik (ed.) Religions, churches and religiosity in postcommunist Europe. Kraków: Nomos, pp. 181-191.

Pasieka, A. 2012. Seven Ways to God: the Dynamics of Religious Pluralism in Rural Southern Poland. Ph.D. Dissertation, Martin Luther University, Halle/Saale.

—. 2012. Czy Łemkowie chodzą w dżinsach? Wielokulturowość w Polsce jako kapitał i jako obciążenie. Pogranicze. Studia Społeczne 20: 35-52.

-. (forth.) Wielokulturowość po polsku. Polityka wielokulturowości jako mechanizm umacniania polskości. Kultura i Społeczeństwo.

Podraza, M. 2009a. Dziewięć a może więcej wyznań. Gazeta Gorlicka, 13.02.2009.

—. 2009b. Uście Gorlickie centrum polskiej ekumenii. Gazeta Krakowska, 14.02.2009.

Reed-Danahay, D. 1993. Talking about Resistance: Ethnography and Theory in Rural France. Anthropological Quarterly 66(4): 221-229.

Scott, J.W. 1992. Multiculturalism and the Politics of Identity. October 61: 12-19.

Smith, M.G. 1960. Social and Cultural Pluralism. Annals of the New York Academy of Sciences 83(5): 763-785.

Turner Terence, 1993. Anthropology and Multiculturalism: What Is Anthropology That Multiculturalists Should Be Mindful of It?, Cultural Anthropology 8(4), s. 411-429.

Verdery, K. 2000. Ethnicity, nationalism, and state-making. In: H. Vermeulen and C. Govers (eds.) The anthropology of ethnicity. Amsterdam: Het Spinhuis, pp. 33-58.

Vertovec S., Wessendorf S., 2009. Assessing the backlash against multiculturalism in Europe, MMG Working Paper, no 09-04.

Vincent, J. 1990. Anthropology and politics: visions, traditions, and trends. Tucson: University of Arizona Press.

Wójtowicz-Huber, B. 2008. Ojcowie narodu. Duchowieństwo greckokatolickie w ruchu narodowym Rusinów galicyjskich (1867-1918). Warszawa: Wydawnictwo Uniwersytetu Warszawskiego. 
Zielińska, K. 2006. Freedom of religion and belief in Poland. In: I. Borowik (ed.) Religions, churches and religiosity in post-communist Europe. Kraków: Nomos, pp. 209-220.

Zubrzycki, G. 2013. Negotiating Pluralism in Québec: Identity, Religion and Secularism in the Debate over 'Reasonable Accommodation'. In: C. Bender, W. Cadge, P. Levitt and D. Smilde (eds.) Religion at the Edge: Toward a New Sociology of Religion. New York: Oxford University Press.

\author{
HOW PLURALISM BECOMES HIERARCHICAL? \\ DEBATING PLURALISM IN CONTEMPORARY POLAND
}

\begin{abstract}
Summary
This article discusses the multifaceted nature of religious pluralism. More specifically, it seeks to answer the question why, while advancing the claims of equality and diversity, the idea of pluralism reproduces inequalities and naturalizes hierarchies. In order to illuminate this problem, the article first presents a theoretical discussion and then refers it to the ethnographic evidence from a yearlong fieldwork in a multireligious locality in southeast Poland. It analyzes the impact of the discourse on "multiculturalism" on minorities' plights and it exposes the processes in which religion, reconfigured as "culture" or "tradition," is used as a discriminatory tool. By combining an exploration of a concrete ethnographic setting with an investigation of the broader implications of locally observed phenomena, it demonstrates the importance of anthropological perspective in the study of pluralism, or rather: the importance of a thorough dialogue between theory and ethnography.
\end{abstract}

Keywords: religious pluralism, anthropology, ethnography, Poland

\author{
DLACZEGO PLURALIZM HIERARCHIZUJE? \\ DYSKUSJA NA TEMAT PLURALIZMU WE WSPÓtCZESNEJ POLSCE
}

\author{
Streszczenie
}

Artykuł podejmuje problem pluralizmu religijnego. Jego celem jest udzielenie odpowiedzi na pytanie dlaczego, mimo iż „pluralizm” promuje różnorodność i równość, równocześnie prowadzi do reprodukowania nierówności i czyni "naturalnymi” hierarchiczne relacje. W tym celu, artykuł w pierwszej kolejności przedstawia teoretyczną dyskusję, następnie zaś łączy ją z obserwacjami z rocznych badań terenowych prowadzonych w wieloreligijnej gminie w południowo-wschodniej Polsce. Poddaje analizie wpływ dyskursu na temat „wielokulturowości” na sytuację mniejszości oraz wyjaśnia, jak religia - rozumiana jako „kulturowy zasób” lub „tradycja” - staje się narzędziem dyskryminacji. Łącząc analizę konkretnego przypadku z refleksją na temat szerszych implikacji badanych zjawisk, artykuł dowodzi znaczenia antropologicznej perspektywy w badaniu pluralizmu, a mówiąc precyzyjniej: znaczenia dialogu między teorią a etnografią. 